\title{
Sensitivity of Isolates of Sclerotium rolfsii from Peanut in Georgia to Selected Fungicides
}

\author{
M. D. Franke, Graduate Student, and T. B. Brenneman, Associate Professor, Department of Plant Pathology, Uni- \\ versity of Georgia Coastal Plain Experiment, Tifton 31793-0748; K. L. Stevenson, Assistant Professor, Department \\ of Plant Pathology, University of Georgia, Athens 30602-7274; and G. B. Padgett, Assistant Professor, University \\ of Georgia Rural Development Center, Tifton 31793-1209
}

\begin{abstract}
Franke, M. D., Brenneman, T. B., Stevenson, K. L., and Padgett, G. B. 1998. Sensitivity of isolates of Sclerotium rolfsii from peanut in Georgia to selected fungicides. Plant Dis. 82:578-583.

The fungicide sensitivity of more than 450 isolates of Sclerotium rolfsii from 11 different peanut fields in Georgia was determined based on percent inhibition of mycelial growth on agar amended with tebuconazole, flutolanil, or PCNB. The 11 locations represented a wide geographic distribution and variety of exposure histories to tebuconazole, flutolanil, and PCNB. Most of the populations sampled were significantly more sensitive than the populations that had the longest exposure to the fungicides. Of the three fungicides tested, tebuconazole and flutolanil demonstrated the strongest positive correlation in 1994 and 1995. The differences in sensitivity among locations suggest that fungicide sensitivity among $S$. rolfsii populations varies across Georgia. The location with the longest exposure history had the lowest sensitivity to all three fungicides.
\end{abstract}

Additional keywords: cross-resistance, sample size

Peanut (Arachis hypogaea L.) plays an important role in the economies of several regions of the United States. The long growing season, warm weather, and available moisture in the Southwest (Oklahoma, Texas), Virginia-Carolina region, and the Southeast (Georgia, Florida, Alabama) make these areas favorable for peanut production. These conditions are also favorable for many fungal peanut pathogens that reduce yield and profits. Stem rot of peanut, caused by Sclerotium rolfsii Sacc., is found in all peanut growing areas. Yield losses can be as high as 25 to $80 \%$ (1). In Georgia, the largest peanut producing state in the United States, stem rot is often a limiting factor, with annual yield losses estimated at $\$ 36.8$ million (University of Georgia Cooperative Extension Service estimates, 1987 to 1994).

Prior to 1994, the options available to growers for stem rot control were limited. Cultural practices that reduce the incidence of stem rot include management of crop residue and crop rotation. Chemical control of stem rot was limited to the use of pentachloronitrobenzene (PCNB) (Uniroyal Chemical, Middlebury, CT) and chlorpyrifos (DowElanco, Indianapolis, IN). How-

Corresponding author: Michael Franke

E-mail: mfranke@tifton.cpes.peachnet.edu

Accepted for publication 10 February 1998.

Publication no. D-1998-0316-02R

(C) 1998 The American Phytopathological Society ever, control with these compounds has often been erratic (14). Recently, two new fungicides, tebuconazole (Bayer Corp., Kansas City, MO) and flutolanil (Agrevo USA Company, Wilmington, DE), were registered for use on peanut $(3,4,13)$. Besides being effective against stem rot, tebuconazole also has activity against early leaf spot (Cercospora arachidicola), late leaf spot (Cercosporidium personatum), rust (Puccinia arachidis), and Rhizoctonia limb rot (Rhizoctonia solani). Flutolanil is effective against stem rot and Rhizoctonia limb rot (13). The introduction of these products gave growers two new options for controlling stem rot. These new fungicides represent a major breakthrough in peanut disease management and have been widely accepted due to their effective control of stem rot and other peanut diseases.

With the expected heavy use of tebuconazole and flutolanil, concerns have been raised over their long-term effectiveness in controlling the target pathogens. Single-site fungicides have a specific mode of action in which one specific biological process within the pathogen is affected, as opposed to multisite fungicides that affect multiple biological processes. Both tebuconazole and flutolanil are single-site fungicides with limited systemic mobility within the plant, but their modes of action are very different. Tebuconazole is a C-14 demethylation inhibitor (DMI) of a biosynthetic step that occurs during the conversion of lanosterol to ergosterol, the final product of fungal sterol synthesis (19). Flutolanil is a benzanilide fungicide that inhibits the succinate dehydrogenase complex of respiration (20). Previous experience with other crops and pathogens has demonstrated the potential for reduced sensitivity to single-site fungicides. Reported uses include triadimenol, tridemorph, and fenpropimorph for Erysiphe graminis f. sp. hordei in barley $(7,9)$, bitertanol for Venturia inaequalis in apple (16), fenarimol and imazalil for Sphaerotheca fuliginea on cucumber (26), and benomyl and carbendazim for Mycosphaerella fijiensis on banana (10).

Monitoring pathogen populations for fungicide sensitivity over time is a good way to determine if resistance is developing. For field monitoring to be of use, distribution of baseline fungicide sensitivity must be established for each target pathogen. However, screening a large number of field isolates collected from several locations on a wide range of fungicide concentrations can be costly and tedious. Because of this, faster methods for monitoring pathogen populations for fungicide sensitivities have been evaluated. Smith et al. (28) used a range of concentrations to establish baseline sensitivity values for several different populations, from which they determined the theoretical sample sizes needed to accurately assess sensitivity. They found a single discriminatory fungicide dose was an effective method for quickly determining the sensitivity of a population to a fungicide, enabling them to sample many locations (28).

With the registration and subsequent heavy use of tebuconazole and flutolanil in peanut, it became prudent to establish a sensitivity monitoring program for $S$. rolfsii from peanut in Georgia. PCNB was also included because of its long history of use in Georgia. The first objective of this study was to examine minimal theoretical sample sizes necessary to detect differences in fungicide sensitivity between two populations as well as a single discriminatory dose of fungicide to use in future studies. Another objective was to quantify the sensitivities of $S$. rolfsii populations from a number of fields that differed in fungicide exposure history. The final objective was to determine if sensitivity values for each fungicide were correlated, indicating possible cross-resistance between fungicides. Since flutolanil and tebuconazole have different modes of action, a possible resis- 
tance management strategy is to rotate their use in alternating years of peanut. For this to be successful, it is important to know if a pathogen developing resistance to one fungicide will be cross-resistant to the other fungicide.

\section{MATERIALS AND METHODS}

Field sites and sampling in 1994. $S$. rolfsii isolates for the study were taken from four Georgia peanut fields. Two fields (Gibbs Farm stem rot nursery, Coastal Plain Experiment Station, Tifton, GA, and the Southwest Branch Experiment Station, Plains, GA) had a history of continuous peanut production and repeated exposure to PCNB, tebuconazole, and flutolanil. The other two locations (Benson Farm, Tift County, and Dry Branch Farm, Lee County) had no exposure to these fungicides. Weeds and insects were controlled at all locations according to recommendations by the Cooperative Extension Service (2).

A stratified sampling pattern was used to collect isolates (6). Each stratum consisted of six beds, each bed consisting of two rows $0.08 \mathrm{~m}$ apart and approximately 30.5 $\mathrm{m}$ long. Ninety to 100 stem sections exhibiting signs of $S$. rolfsii infection were collected from each field. The infected stem sections were cut into three sections (approximately $3 \mathrm{~cm}$ long) and surface disinfested with a $0.525 \%$ sodium hypochlorite solution for $2 \mathrm{~min}$. Stem pieces were then placed on $9.5-\mathrm{cm}$-diameter petri dishes containing potato dextrose agar (PDA) amended with chlortetracycline and chloramphenicol at $100 \mu \mathrm{g} / \mathrm{ml}$. The cultures were incubated at 24 to $25^{\circ} \mathrm{C}$ for 24 h. A hyphal plug of each isolate was transferred to a 60-mm-diameter petri dish of PDA and incubated at $26^{\circ} \mathrm{C}$ until mature sclerotia formed (approximately 1 week). One mature sclerotium from each isolate was transferred to another large petri dish containing PDA and incubated at $27^{\circ} \mathrm{C}$ for approximately 3 days to provide a source of mycelium for the fungicide sensitivity assay.

Baseline sensitivity determination. The sensitivity of 72 to 75 isolates of $S$. rolfsii from each field was established for tebuconazole, flutolanil, and PCNB. Technical grade active ingredient of each fungicide was used, and all dilutions were made in acetone. The fungicides were dissolved in acetone before mixing with PDA that had been cooled to $60^{\circ} \mathrm{C}$. The final concentration of acetone in all plates (nonamended controls included) was $0.05 \%$ ( $\mathrm{vol} / \mathrm{vol})$. The concentrations of tebuconazole and flutolanil were 5, 1, 0.5, $0.1,0.05,0.01,0.005,0.001$, and 0.0005 $\mu \mathrm{g} / \mathrm{ml}$ of medium. The concentrations of PCNB were 50, 20, 10, 5, 2, 1, 0.5, 0.2, and $0.1 \mu \mathrm{g} / \mathrm{ml}$ of medium. Hyphal plugs (1 $\mathrm{cm}$ diameter) from the edge of actively growing colonies on PDA were transferred to the edge of 9.5 -cm-diameter petri dishes containing approximately $22 \mathrm{ml}$ of PDA amended with each of the nine different concentrations of fungicide or one nonamended control. Inoculated plates were incubated at $26^{\circ} \mathrm{C}$ for 3 days. Radial mycelial growth was measured in millimeters (from the edge of the inoculum plug) after 3 days. The concentration of fungicide causing a $50 \%$ reduction in growth compared with nonamended controls $\left(\mathrm{ED}_{50}\right.$ value) was determined for each fungicide by regressing the percent inhibition [100 (colony diameter on amended medium $\div$ colony diameter on control $\times 100$ )] against the logarithm (base 10) of fungicide concentration.

Sample size. For establishing the baseline sensitivity values for each fungicide, a sample size of 75 isolates was chosen. To reduce the amount of time and materials needed to determine sensitivities, a method outlined by Snedecor and Cochran was used to estimate minimal required sample sizes (29). Sample sizes were determined independently for each fungicide. Each sample size was based on the weighted mean average of the variance of $\mathrm{ED}_{50}$ values calculated for each field and fungicide sampled in 1994. The means were weighted according to the number of samples collected from each location in 1994. These sample sizes are the fewest number of samples needed for each fungicide to detect approximately a $10 \%$ difference in mean percent inhibition at a discriminatory dose between any two populations ( $\alpha=$ 0.05 and $90 \%$ confidence limits).

Field sites and sampling in 1995. Eleven Georgia peanut fields were sampled from July to September. Fields were located throughout the peanut belt from Seminole County in the southwest to Jenkins County in the eastern part of the state. Plants in these fields exhibited varying degrees of stem rot infection. All locations, with the exception of the Tift County no. 2 farm, were on a 2-year or longer rotation, and fungicide exposure histories varied for each field. Weeds and insects were controlled at all locations using recommendations by the Cooperative Extension Service (2).

Sample sizes for each fungicide were based on results of the baseline sensitivity study conducted in 1994. For the 1995 study, sample sizes of 31 to 50 isolates from each location were actually tested. Diseased peanut stem sections with mature sclerotia were collected from each field using a stratified sampling pattern (6). Each stratum consisted of eight beds, each bed consisting of two rows $0.08 \mathrm{~m}$ apart and approximately $30.5 \mathrm{~m}$ long. However, the size of each stratum varied depending on the size of the field being sampled.

Three mature sclerotia were removed from each infected stem section, surface disinfested with a solution of $0.525 \%$ sodium hypochlorite for $1 \mathrm{~min}$, and placed on petri dishes containing PDA amended with chlortetracycline and chloramphenicol at $100 \mu \mathrm{g} / \mathrm{ml}$ each. Sclerotia were incubated at $30^{\circ} \mathrm{C}$ until eruptive germination occurred ( 24 to $36 \mathrm{~h}$ ). Hyphal tips of one actively growing colony were transferred from each petri dish to petri dishes containing PDA to provide mycelium for the sensitivity assay.

Sensitivity assay in 1995. Hyphal plugs (1 cm diameter) from the edge of actively growing colonies on PDA were transferred to the edge of 9.5 -cm-diameter petri dishes containing approximately $22 \mathrm{ml}$ of PDA either nonamended or amended with a single discriminatory dose of fungicide (technical grade active ingredient). Discriminatory doses used in the assay for tebuconazole, flutolanil, and PCNB were $0.02,0.03$, and $2.0 \mu \mathrm{g} / \mathrm{ml}$, respectively. Discriminatory doses were chosen based on percent inhibition of hyphal growth at a specific concentration for each fungicide from the four locations sampled in 1994. Fungicide amendments and growth measurements were as described previously. Percent inhibition was determined for each isolate, and a mean percent inhibition was determined for each location.

Data analysis. The range and mean $\mathrm{ED}_{50}$ values were calculated for each location sampled in 1994. For each fungicide and location, a resistance factor was determined. This was expressed as the ratio of the highest $\mathrm{ED}_{50}$ to the mean $\mathrm{ED}_{50}$ for a given field population and can be used as an indicator of the risk of developing resistance $(8,28)$. Homogeneity of the variances was tested using Hartley's test statistic (24). Differences in mean $\mathrm{ED}_{50}$ values between treated and nontreated locations sampled in 1994 were determined using single degree of freedom linear contrasts in the general linear models procedure of PC-SAS (Statistical Analysis System, SAS Institute, Cary, NC).

The range and mean percent inhibition were calculated for each location sampled in 1995. Differences in mean percent inhibition among locations were determined using ANOVA, and means were separated using Fisher's protected LSD. Correlation in fungicide sensitivity was determined for the fungicides evaluated in 1994 and 1995 by calculating Pearson correlation coefficients using PC-SAS.

\section{RESULTS}

1994 sensitivity assay. There was a wide range in mean $\mathrm{ED}_{50}$ values from each of the four locations sampled. There were differences in sensitivities for each fungicide tested among the four locations (Tables 1 to 3 ). The $\mathrm{ED}_{50}$ values ranged from 0.0008 to $0.14,0.002$ to 0.14 , and 0.41 to $17.70 \mu \mathrm{g} / \mathrm{ml}$ for tebuconazole, flutolanil, and PCNB, respectively. However, the frequency distributions for each location were lognormally distributed. There was homogeneity of variances across all locations when tested using Hartley's test 
statistic. Therefore, locations with similar exposure histories were combined, and a less specific frequency distribution was constructed. When the data were combined, there were significant differences flutolanil $(P \leq 0.0006)$ and PCNB $(P \leq$ $0.0001)$ from locations having repeated exposure to the fungicides when compared with isolates from locations that had no previous exposure to the fungicides. Mean $\mathrm{ED}_{50}$ values of isolates from the fields with previous exposure to the fungicides were lower than those values from the fields with no prior exposure history. There were no differences $(P=0.2763)$ in $\mathrm{ED}_{50}$ values among combined locations for tebuconazole. All the resistance factors for tebubetween mean $\mathrm{ED}_{50}$ values of isolates for

conazole, flutolanil, and PCNB were between 2.7 and 10.8, with the exception of Sumter County, which had a resistance factor of 20.0 to tebuconazole.

Based on the $\mathrm{ED}_{50}$ values from the four locations, estimated required minimal sample sizes to detect a $10 \%$ difference in mean sensitivity between any two pathogen populations were determined for a $0.05 \%$ level of significance. Sample sizes of 20,35 , and 78 were calculated for tebuconazole, flutolanil, and $\mathrm{PCNB}$, respectively (Fig. 1).

The $\mathrm{ED}_{50}$ values for tebuconazole and flutolanil were positively correlated $(r=$ $0.560, P \leq 0.0001)$, as were $\mathrm{ED}_{50}$ values for tebuconazole and PCNB $(r=0.134, P$ $\leq 0.0218)$. However, the $\mathrm{ED}_{50}$ values for

Table 1. Sensitivity distribution of isolates of Sclerotium rolfsii collected from four locations in Georgia in 1994 to tebuconazole

\begin{tabular}{|c|c|c|c|c|c|}
\hline \multirow[b]{3}{*}{ Location $^{\text {a }}$} & \multirow[b]{3}{*}{ Isolates } & & & \multicolumn{2}{|c|}{ Variation in population } \\
\hline & & \multicolumn{2}{|c|}{$\mathrm{ED}_{50}(\mu \mathrm{g} / \mathrm{ml})$} & \multirow{2}{*}{$\begin{array}{l}\text { Resistance } \\
\text { factor }^{c}\end{array}$} & \multirow{2}{*}{$\begin{array}{c}\text { Standard error } \\
\text { of mean }\end{array}$} \\
\hline & & Range & Mean $^{b}$ & & \\
\hline Gibbs Farm (T) & 76 & 0.006 to 0.11 & 0.020 & 5.5 & 0.0291 \\
\hline Sumter Co. (T) & 76 & 0.0008 to 0.14 & 0.007 & 20.0 & 0.0482 \\
\hline Combined (T) & 152 & 0.0008 to 0.14 & $0.013 \mathrm{a}$ & 10.8 & 0.0018 \\
\hline Benson Farm (U) & 72 & 0.008 to 0.09 & 0.023 & 3.9 & 0.0249 \\
\hline Lee Co. (U) & 71 & 0.0009 to 0.04 & 0.007 & 5.7 & 0.0366 \\
\hline Combined (U) & 143 & 0.0009 to 0.09 & $0.015 \mathrm{a}$ & 6.0 & 0.0011 \\
\hline
\end{tabular}

a $\mathrm{T}=$ treated site previously exposed to multiple applications of tebuconazole.

${ }^{\mathrm{b}}$ Means followed by the same letter are not significantly different using single degree of freedom contrasts in the PC-SAS general linear models procedure $(\alpha=0.05)$.

${ }^{\mathrm{c}}$ Resistance factor $=\left(\right.$ maximum $\mathrm{ED}_{50} \div$ mean $\left.\mathrm{ED}_{50}\right)$.

Table 2. Sensitivity distribution of isolates of Sclerotium rolfsii collected from four locations in Georgia in 1994 to flutolanil

\begin{tabular}{|c|c|c|c|c|c|}
\hline \multirow[b]{3}{*}{ Location $^{\text {a }}$} & \multirow[b]{3}{*}{ Isolates } & & & \multicolumn{2}{|c|}{ Variation in population } \\
\hline & & \multicolumn{2}{|c|}{$\mathrm{ED}_{50}(\mu \mathrm{g} / \mathrm{ml})$} & \multirow{2}{*}{$\begin{array}{c}\text { Resistance } \\
\text { factor }^{c}\end{array}$} & \multirow{2}{*}{$\begin{array}{c}\text { Standard error } \\
\text { of mean }\end{array}$} \\
\hline & & Range & Mean $^{b}$ & & \\
\hline Gibbs Farm (T) & 76 & 0.007 to 0.090 & 0.033 & 2.7 & 0.0200 \\
\hline Sumter Co. (T) & 76 & 0.004 to 0.140 & 0.020 & 7.0 & 0.0267 \\
\hline Combined (T) & 152 & 0.004 to 0.140 & $0.026 \mathrm{a}$ & 5.4 & 0.0014 \\
\hline Benson Farm (U) & 72 & 0.22 to 0.140 & 0.050 & 2.8 & 0.0185 \\
\hline Lee Co. (U) & 71 & 0.002 to 0.035 & 0.009 & 3.9 & 0.0262 \\
\hline Combined (U) & 143 & 0.022 to 0.140 & $0.029 \mathrm{~b}$ & 4.8 & 0.0021 \\
\hline
\end{tabular}

a $\mathrm{T}=$ treated site previously exposed to multiple applications of flutolanil.

${ }^{\mathrm{b}}$ Means followed by the same letter are not significantly different using single degree of freedom contrasts in the PC-SAS general linear models procedure $(\alpha=0.05)$.

${ }^{\mathrm{c}}$ Resistance factor $=$ maximum $\mathrm{ED}_{50} \div$ mean $\mathrm{ED}_{50}$.

Table 3. Sensitivity distribution of isolates of Sclerotium rolfsii collected from four locations in Georgia in 1994 to PCNB

\begin{tabular}{|c|c|c|c|c|c|}
\hline \multirow[b]{3}{*}{ Location $^{\mathbf{a}}$} & \multirow[b]{3}{*}{ Isolates } & & & \multicolumn{2}{|c|}{ Variation in population } \\
\hline & & \multicolumn{2}{|c|}{$\mathbf{E D}_{50}(\mu \mathrm{g} / \mathrm{ml})$} & \multirow{2}{*}{$\begin{array}{l}\text { Resistance } \\
\text { factor }^{c}\end{array}$} & \multirow{2}{*}{$\begin{array}{c}\text { Standard error } \\
\text { of mean }\end{array}$} \\
\hline & & Range & Mean $^{b}$ & & \\
\hline Gibbs Farm $(\mathrm{T})$ & 76 & 0.54 to 5.03 & 1.55 & 3.2 & 0.0235 \\
\hline Sumter Co. (T) & 76 & 0.41 to 2.44 & 0.84 & 2.9 & 0.0191 \\
\hline Combined $(\mathrm{T})$ & 152 & 0.41 to 5.03 & $1.20 \mathrm{a}$ & 4.2 & 0.0649 \\
\hline Benson Farm (U) & 72 & 0.50 to 4.50 & 1.66 & 2.7 & 0.0220 \\
\hline Lee Co. (U) & 71 & 0.80 to 17.70 & 2.24 & 7.9 & 0.0275 \\
\hline Combined (U) & 143 & 0.50 to 17.70 & $1.95 \mathrm{~b}$ & 9.1 & 0.1406 \\
\hline
\end{tabular}

a $\mathrm{T}=$ treated site previously exposed to multiple applications of PCNB.

${ }^{b}$ Means followed by the same letter are not significantly different using single degree of freedom contrasts in the PC-SAS general linear models procedure $(\alpha=0.05)$.

${ }^{\mathrm{c}}$ Resistance factor $=$ maximum $\mathrm{ED}_{50} \div$ mean $\mathrm{ED}_{50}$.
PCNB and flutolanil were not significantly correlated ( $r=0.047, P \leq 0.4265)$.

1995 sensitivity assay. Varying degrees of sensitivity to each fungicide were observed across locations (Tables 4 to 6). Isolates from all of the locations, except one, were more sensitive $(P \leq 0.05)$ to tebuconazole, and all were more sensitive to flutolanil and PCNB than those from the Tift County no. 2 location. This field had been planted continuously to peanut for approximately 15 years and was used to evaluate fungicides, including the three in this study. Sensitivities to tebuconazole and flutolanil again demonstrated the strongest positive correlation $(r=0.401, P$ $\leq 0.0001)$; sensitivities to flutolanil and PCNB were weakly correlated $(r=0.158$, $P \leq 0.001)$; and sensitivities to tebuconazole and PCNB were not correlated $(r=$ $-0.040, P \leq 0.4053)$.

\section{DISCUSSION}

Field monitoring is one method to assess the development of fungicide resistance. Resistance, according to Delp and Dekker (8), is a stable, inheritable adjustment by the fungus to a fungicide, resulting in a less-than-normal sensitivity to that fungicide. The rate at which resistance develops varies depending upon the type of selection process for a resistant subpopulation.

Field monitoring using a wide range of concentrations and establishing a mean $\mathrm{ED}_{50}$ value can help determine which selection process is occurring and the likelihood of a rapid loss of disease control in the field (27). In the case of benomyl, where pathogen resistance developed very quickly, a disruptive selection process was observed, and a distinct resistant subpopulation developed $(17,22)$. This resistant subpopulation was free to proliferate at fungicide concentrations that gave adequate control of the wild-type sensitive subpopulation. DMI fungicides exhibit a directional selection process, indicating the resistance mechanism may be under the influence of many genes, or at least more than one (11,12). A distinct resistant subpopulation probably will not be found, but the entire population will gradually shift toward a decreased sensitivity over time (19).

Frequency distributions of the pooled data for each of the fungicides used in the study in 1994 demonstrate a continuous population exhibiting one distinct population with a wide range of sensitivity. This is similar to distributions described for pathogens that have been exposed to other site-specific fungicides $(26,28)$. Each individual location was lognormally distributed, and there was not a small resistant subpopulation present. To determine if directional selection is occurring, the same populations would need to be monitored over time to determine if a shift toward a decreased sensitivity occurs. This is necessary for pathogens that exhibit hetero- 
karyosis, such as $S$. rolfsii (25). The proportion of nuclei carrying a resistant gene initially may be very small, and long exposures may be required to increase this proportion to substantially affect the phenotype. The stability of heterokaryosis could also have an effect on the length of time needed for the pathogen population to exhibit a resistant phenotype (25).

Due in part to the large number of isolates from each location in 1994, significant differences were detected in mean sensitivity to flutolanil and PCNB between treated and nontreated locations, but because the differences were small they are probably not biologically meaningful. Surprisingly, isolates from the treated locations had lower mean $\mathrm{ED}_{50}$ values than those from nontreated locations. This is consistent with results obtained from a similar study in Texas (Ken Woodard, personal communication). It is not clear why this is happening. Several factors, such as weather, sampling period, or pesticide exposure, could have an effect on the "vigor" of the isolates. However, in this study, all isolates were collected within a short period in late summer; both paired locations were relatively close to each other; and the developmental stages of the plants in the field at the time of collection were very similar. As demonstrated by the study conducted in 1995 , this is probably a result of natural variability in sensitivity to the fungicides.

Resistance factors for populations in all locations except Sumter County (exposed to tebuconazole) were very similar. The higher resistance factor for isolates from Sumter County does not necessarily imply that resistance will become a problem. The wide range of $\mathrm{ED}_{50}$ values and a low mean $\mathrm{ED}_{50}$ value for that location indicate a wider range in sensitivity among isolates within that population. As the range of sensitivity increases, the risk of individuals becoming less sensitive to the fungicide than the rest of the population also increases.

Another important aspect of establishing baseline sensitivity values is determining the appropriate sample sizes needed to accurately assess the differences in the sensitivity between field populations. In the present study, sample sizes were estimated separately for each fungicide based on the variability in sensitivity of $S$. rolfsii populations. The smallest sample size calculated was for flutolanil, which had the least variation in $\mathrm{ED}_{50}$ values, while the largest was for PCNB. The sample sizes calculated for the fungicides used in this study are similar to those needed to monitor fungicide sensitivity of $V$. inaequalis to flusilazole in New York (28). Smith et al. found that 50 monoconidial isolates were sufficient to detect a shift toward a decreased sensitivity in a population of $V$. inaequalis. The sample sizes calculated are only valid for the fungicides tested, and an increase in the number of individuals less sensitive to the fungicides could significantly change the variance, which would alter the minimum sample sizes.

Although it cannot be demonstrated conclusively, the results obtained from the study in 1995 indicate that exposure history may have had an effect on fungicide sensitivity. It cannot be determined if the locations with the lowest sensitivities were originally less sensitive to the fungicide, or if the sensitivity shifted over time as a result of exposure to the fungicide. However, for all three fungicides, the location with the lowest sensitivity was the site with the most intensive exposure history, i.e., the research plots in the Tift County no. 2 field. Petri dishes amended with PCNB actually had more mycelial growth than the nonamended controls. For PCNB, the location with the next lowest sensitivity also had a long exposure history to PCNB. For tebuconazole, the three locations with the lowest sensitivities had very different exposure histories. The fields in Coffee and Berrien counties had each been treated for 1 year only, receiving two and four applications of tebuconazole, respectively. Despite the applications of tebuconazole, there was a substantial amount of disease present in both fields. However, this was probably an application problem rather than a poor response by the pathogen to the fungicide. The Tift County no. 2 location had been exposed to tebuconazole for many years in small plots throughout the field. Although isolates from this field had the lowest sensitivity to tebuconazole, disease control has not been noticeably altered.

There was less variability in sensitivity of isolates among locations exposed to flutolanil. Again, the location with the lowest sensitivity to flutolanil also had the longest exposure history to the fungicide, but it cannot be determined if this was due to exposure or an original population that was less sensitive. There was only one other location (Seminole County) that had received any applications of flutolanil.

Because there are apparently populations of $S$. rolfsii with naturally lower sensitivities to tebuconazole, it is conceivable that a decrease in sensitivity could occur more quickly and lead to poor disease control in the field. This is particularly true if decreased sensitivity remains stable over a period of time.

Tebuconazole and flutolanil are both site-specific fungicides, but their modes of action are distinct. Therefore, a possible resistance management strategy could be to rotate these two fungicides in alternating years or within 1 year of peanut. To evaluate the potential success of this strategy, it is important to determine if sensitivity to one fungicide is correlated with sensitivity

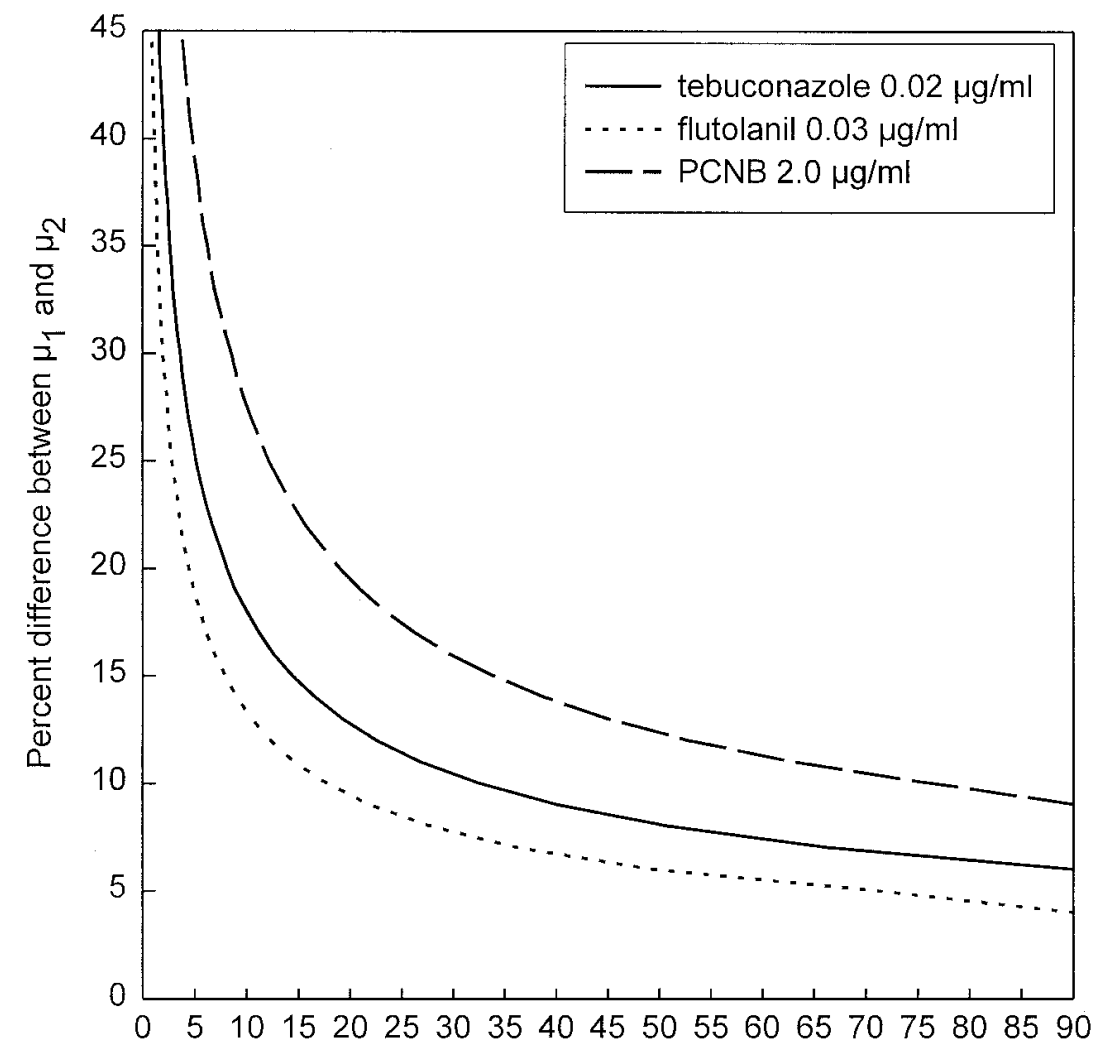

\section{Sample size}

Fig. 1. Estimated minimum sample sizes necessary to detect differences between mean percent inhibition on a particular fungicide concentration of populations of Sclerotium rolfsii. Sample sizes are based on a significance level of 0.05 . 
to the other fungicide. If there is a correlation between sensitivities of any two fungicides, then it is likely that isolates that are resistant to one fungicide will be resistant to the other. This has been reported for the DMI fungicides flusilazole, etaconazole, fenarimol, bitertanol, buthiobate, and imazalil $(15,26)$.

There was a correlation in sensitivity in 1994 and 1995 between tebuconazole and

Table 4. Sensitivity of isolates of Sclerotium rolfsii sampled from each of 11 locations in Georgia in 1995 to tebuconazole

\begin{tabular}{lcccc}
\hline & & \multicolumn{2}{c}{ inhibition $^{\mathbf{a}}$} & $\begin{array}{c}\text { Standard error } \\
\text { Lsocation }\end{array}$ \\
\cline { 2 - 3 } & Isolates & Range & Mean $^{\mathbf{b}}$ & 1.378 \\
\hline Berrien Co. & 50 & 6.00 to 43.00 & 25.00 & 1.249 \\
Coffee Co. & 45 & 3.00 to 38.00 & 19.60 & 2.677 \\
Colquitt Co. & 41 & -19.0 to 79.00 & 25.90 & 1.809 \\
Dougherty Co. & 46 & 5.00 to 63.00 & 33.80 & 1.332 \\
Jenkins Co. & 42 & 17.00 to 59.00 & 38.10 & 1.630 \\
Miller Co.1 & 46 & 7.00 to 59.00 & 34.40 & 2.130 \\
Miller Co. 2 & 31 & -9.00 to 44.00 & 27.40 & 2.420 \\
Montgomery Co. & 39 & -21.00 to 53.00 & 26.80 & 2.530 \\
Seminole Co. & 38 & -54.00 to 45.00 & 27.50 & 3.168 \\
Tift Co. 1 & 47 & -25.00 to 73.00 & 31.60 & 0.904 \\
Tift Co. 2 & 48 & -19.00 to 44.00 & 18.70 & \\
LSD & & & 5.5 &
\end{tabular}

a Percent inhibition was calculated as $100-[$ (colony diameter on amended medium $\div$ colony diameter on controls $) \times 100$ ] for isolates on potato dextrose agar amended with tebuconazole at 0.02 $\mu \mathrm{g} / \mathrm{ml}$.

${ }^{\mathrm{b}}$ Means followed by the same letter are not significantly different $(P>0.05)$ using Fisher's protected LSD.

Table 5. Sensitivity of isolates of Sclerotium rolfsii sampled from each of 11 locations in Georgia in 1995 to flutolanil

\begin{tabular}{lcccc}
\hline & & \multicolumn{2}{c}{ \% inhibition } & Standard error \\
Location & Isolates & Range & Mean $^{\mathbf{b}}$ & of mean \\
\hline Berrien Co. & 50 & 10.00 to 46.00 & 34.60 & 1.022 \\
Coffee Co. & 45 & 15.00 to 56.00 & 33.30 & 1.282 \\
Colquitt Co. & 41 & -11.10 to 54.00 & 33.10 & 1.730 \\
Dougherty Co. & 46 & -40.00 to 45.00 & 24.10 & 2.378 \\
Jenkins Co. & 42 & 11.00 to 49.00 & 32.50 & 1.173 \\
Miller Co.1 & 46 & 14.00 to 45.00 & 31.40 & 1.090 \\
Miller Co. 2 & 31 & 11.00 to 45.00 & 30.30 & 1.681 \\
Montgomery Co. & 39 & -14.00 to 47.00 & 24.40 & 2.076 \\
Seminole Co. & 38 & -31.00 to 53.00 & 32.30 & 2.059 \\
Tift Co. 1 & 47 & 0.00 to 62.00 & 36.10 & 1.936 \\
Tift Co. 2 & 48 & -25.00 to 49.00 & 18.80 & 0.618 \\
LSD & & 4.4 & \\
\hline
\end{tabular}

a Percent inhibition was calculated as $100-[$ (colony diameter on amended medium $\div$ colony diameter on controls $) \times 100$ ] for isolates on potato dextrose agar amended with flutolanil at 0.03 $\mu \mathrm{g} / \mathrm{ml}$.

${ }^{\mathrm{b}}$ Means followed by the same letter are not significantly different $(P>0.05)$ using Fisher's protected LSD.

Table 6. Sensitivity of isolates of Sclerotium rolfsii sampled from each of 11 locations in Georgia in 1995 to PCNB

\begin{tabular}{lcccc}
\hline & & \multicolumn{2}{c}{ \% inhibition } & Standard error \\
\cline { 3 - 4 } Location & Isolates & Range & Mean $^{\mathbf{b}}$ & \multirow{2}{*}{\begin{tabular}{c} 
of mean \\
\hline Berrien Co.
\end{tabular}} \\
\cline { 3 - 4 } Coffee Co. & 50 & 4.00 to 91.00 & 43.40 & 4.190 \\
Colquitt Co. & 45 & 14.00 to 88.00 & 63.90 & 3.194 \\
Dougherty Co. & 41 & 38.00 to 93.00 & 77.60 & 1.963 \\
Jenkins Co. & 46 & -38.00 to 89.00 & 26.10 & 5.193 \\
Miller Co.1 & 42 & 0.00 to 89.00 & 35.60 & 4.935 \\
Miller Co. 2 & 46 & -8.00 to 69.00 & 29.10 & 2.818 \\
Montgomery Co. & 31 & 4.00 to 91.00 & 32.50 & 5.590 \\
Seminole Co. & 39 & -6.00 to 93.00 & 48.90 & 5.390 \\
Tift Co. 1 & 38 & 0.00 to 87.00 & 36.90 & 5.042 \\
Tift Co. 2 & 47 & 5.00 to 92.00 & 69.90 & 2.988 \\
LSD & 48 & -47.20 to 64.00 & -1.40 & 0.616 \\
\hline
\end{tabular}

a Percent inhibition was calculated as $100-[$ (colony diameter on amended medium $\div$ colony diameter on controls) $\times 100$ ] for isolates on potato dextrose agar amended with PCNB at $2.00 \mu \mathrm{g} / \mathrm{ml}$.

${ }^{\mathrm{b}}$ Means followed by the same letter are not significantly different $(P>0.05)$ using Fisher's protected LSD. flutolanil. These data suggest that using these two fungicides in rotation may not offer the grower as much advantage in reducing the development of resistance as might be speculated based on mode of action alone. However, there have been no reports of cross-resistance between DMIs and fungicides with different modes of action.

This is the first comprehensive report of sensitivity of $S$. rolfsii to tebuconazole and flutolanil. Once the baseline sensitivity values and sample sizes had been established for each fungicide, the use of a discriminatory dose of fungicide, rather than a range of concentrations, seemed to work well and allowed the sensitivity of isolates from many locations to be determined quickly. The differences between the mean $\mathrm{ED}_{50}$ values for tebuconazole and flutolanil compared with PCNB (approximately $100 \times$ ) indicate the effectiveness of these new chemicals in controlling stem rot. Due to this level of activity, they are extremely important disease management tools, and every effort should be made to maintain their efficacy.

Future work should concentrate on determining if there is a reduction in efficacy of fungicides in the field for isolates that show a lower in vitro sensitivity. In some cases, research has shown that the most resistant members of a population are also less fit in the absence of fungicide exposure (9). This leaves the strains with intermediate sensitivity as the predominant part of the population; thus adequate control of the pathogen in the field may still be attainable.

There are several factors affecting the development of resistance other than the mode of action of the fungicide. The biology of the fungus plays a significant role in the development of fungicide resistance. $S$. rolfsii is a basidiomycete that reproduces vegetatively and does not produce asexual spores. Studies have shown that mycelial compatibility groups (MCG) and vegetative compatibility groups (VCG) play a significant role in the exchange of genetic information in fungi where the sexual stage does not play a role in the disease cycle $(18,21,23)$. Isolates of $S$. rolfsii that become resistant to the fungicide may take longer to reach a level in the population necessary for a disease control failure to occur than do pathogens that are prolific at producing secondary inoculum. Research in Texas indicates that a small number of MCG exist within a single peanut field, with usually one MCG found on a single plant (23). Results from the study also indicate that MCG are clonal and that exchange of genetic information is going to be limited to isolates within the same MCG. A fungicideresistant isolate would only be able to pass this trait to isolates within the same MCG, thus delaying the development of a resistant population if that MCG was not predominant in the field. 
Dispersal of the pathogen is also important. Because there are not any secondary cycles of inoculum produced, movement of the pathogen occurs through any mechanism capable of moving soil or plant debris. Therefore, the movement of any isolates with lower fungicide sensitivities across the field will take longer than movement of pathogens that are readily dispersed by wind, rain, or insect vectors. The gradual selection pressure exerted on the pathogen by the fungicide, and the fact that many applications of fungicide are not required each year for control of stem rot, are also important. However, use of sitespecific fungicides for control of foliar pathogens of peanut and of crops grown in rotation with peanut could increase the risk of resistance developing, not only in $S$. rolfsii, but in other pathogens as well. Although the risk of resistance developing in $S$. rolfsii seems low to moderate, the use of practices to reduce the incidence of the disease (crop rotation, resistant cultivars, proper management of crop debris, etc.) should be utilized to minimize that risk (5). This will help ensure that these new fungicides remain an important part of the grower's disease management program.

\section{ACKNOWLEDGMENTS}

This research was supported in part by a grant from the Georgia Commodity Commission for Peanuts and Bayer Corporation, Kansas City, MO. We thank Stephanie Curry, Amy Burleigh, Patrick Cowan, Kevin Joyce, and Sandra Welch for technical assistance, and Bayer Corporation, Agrevo USA Company, Wilmington, DE, and Uniroyal Chemical, Middlebury, CT, for providing fungicides used in this study.

\section{LITERATURE CITED}

1. Backman, P. A. 1990. Soilborne diseases. Pages 15-16 in: Compendium of Peanut Diseases. 2nd ed. D. M. Porter, D. H. Smith, and R. Rodriguez-Kabana, eds. American Phytopathological Society, St. Paul, MN.

2. Beasley, J. P., Baldwin, J. A., Brown, S. L., Brown, S. M., Padgett, G. B., Bader, M., and Shurley, D. 1995. Georgia Peanut Production Guide. University of Georgia Coop. Ext. Serv.
Bull. 95-001.

3. Brenneman, T. B., and Murphy, A. P. 1991. Activity of tebuconazole on Cercosporidium personatum, a foliar pathogen of peanut. Plant Dis. 75:699-703.

4. Brenneman, T. B., Murphy, A. P., and Csinos, A. S. 1991. Activity of tebuconazole on Sclerotium rolfsii and Rhizoctonia solani, two soilborne pathogens of peanut. Plant Dis. 75:744-747.

5. Brent, K. J. 1995. Fungicide Resistance in Crop Pathogens: How Can it Be Managed? Pages 1-48 in: FRAC, GFIAP, Brussels.

6. Campbell, C. L., and Madden, L. V. 1990. Designing experiments and sampling. Pages 353-391 in: Introduction to Plant Disease Epidemiology. C. L. Campbell and L. V. Madden, eds. John Wiley \& Sons, New York.

7. Clark, W. S. 1992. Practical aspects of resistance to DMI fungicides in barley powdery mildew Erysiphe graminis. Proc. Brighton Crop Prot. Conf., Pests Dis. 1:177-182.

8. Delp, C. J., and Dekker, J. 1985. Fungicide resistance: Definitions and use of terms. EPPO Bull. 15:569-574.

9. Fletcher, J. T., and Wolfe, M. S. 1981. Insensitivity of Erysiphe graminis f. sp. hordei to triadimefon, triadimenol, and other fungicides. Proc. Brighton Crop Prot. Conf., Pests Dis. 633-640.

10. Fullerton, R. A., and Tracey, G. M. 1984. Tolerance of Mycosphaerella fijiensis to benomyl and carbendazim in the Pacific islands. Trop. Agric. (Trinidad) 61(2):133-136.

11. Georgopoulos, S. G. 1985. The genetic basis of classification of fungicides according to resistance risk. EPPO Bull. 15:513-517.

12. Georgopoulos, S. G., and Zarcovtis, C. 1986. Genetic variability in the fungi and the problem of fungicide resistance. Crop Prot. 5:299305.

13. Hagan, A. K., Weeks, J. R., and Bowen, K. 1991. Effects of application timing and method on control of southern stem rot of peanut with foliar-applied fungicides. Peanut Sci. 18:47-50.

14. Hagan, A. K., Weeks, J. R., and McGuire, J. A. 1988. Comparison of soil insecticides alone and in combination with PCNB for suppression of southern stem rot of peanut. Peanut Sci. 15:35-38.

15. Henry, M. J., and Trivellas, A. E. 1989. Laboratory-induced fungicide resistance to benzimidazole and azole fungicides in Cercospora beticola. Pestic. Biochem. Physiol. 35:89-96.

16. Hildebrand, P. D., Lockhart, C. L., Newbery,
R. J., and Ross, R. G. 1988. Resistance of Venturia inaequalis to bitertanol and other demethylation inhibiting fungicides. Can. J. Plant Pathol. 10:311-316.

17. Koenradt, H., Somerville, S. C., and Jones, A. L. 1992. Characterization of mutations in the betatubulin gene of benomyl-resistant field strains of Venturia inaequalis and other plant pathogenic fungi. Phytopathology 82:1348-1354.

18. Kohn, L. M., Stasovski, E., Carbone, I. Royer, J., and Anderson, J. B. 1991. Mycelial incompatibility and molecular markers identify genetic variability in field populations of Sclerotinia sclerotiorum. Phytopathology 81:480-485.

19. Köller, W., and Scheinpflug, H. 1987. Fungal resistance to sterol biosynthesis inhibitors: A new challenge. Plant Dis. 71:1066-1074.

20. Leroux, P. 1996. Recent developments in the mode of action of fungicides. Pestic. Sci. 47:191-197.

21. Leslie, J. F. 1993. Fungal vegetative compatibility. Annu. Rev. Phytopathol. 31:127-150.

22. Littrell, R. H. 1974. Tolerance in Cercospora arachidicola to benomyl and related fungicides. Phytopathology 64:1377-1378.

23. Nalim, F. A., Starr, J. L., Woodard, K. E., Segner, S., and Keller, N. P. 1995. Mycelial compatibility groups in Texas peanut field populations of Sclerotium rolfsii. Phytopathology 85:1507-1512.

24. Ott, R. L. 1993. Checking on the equal variance assumption. Pages 785-792 in: An Introduction to Statistical Methods and Data Analysis. R. L. Ott, ed. Duxbury Press, Belmont, CA.

25. Parmeter, J. R., Jr., Snyder, W. C., and Reichle, R. E. 1963. Heterokaryosis and variability in plant-pathogenic fungi. Annu. Rev. Phytopathol. 1:51-76.

26. Schepers, H. T. A. M. 1985. Changes during a three-year period in the sensitivity to ergosterol biosynthesis inhibitors of Sphaerotheca fuliginea in the Netherlands. Neth. J. Plant Pathol. 91:105-118.

27. Skylakakis, C. 1985 . Two different processes for the selection of fungicide-resistant subpopulations. EPPO Bull. 15:519-525.

28. Smith, F. D., Parker, D. M., and Köller, W. 1991. Sensitivity distribution of Venturia inaequalis to the sterol demethylation inhibitor flusilazole: Baseline sensitivity and implications for resistance monitoring. Phytopathology 81:392-396.

29. Snedecor, G. W., and Cochran, W. G. 1980. Statistical Methods. 6th ed. Iowa State University, Ames. 